\title{
Detection of analyte binding to microarrays using gold nanoparticle labels and a desktop scanner
}

Han, Anpan; Dufva, Martin; Belleville, Erik; Christensen, Claus Bo Vöge

Published in:

Lab on a Chip

Link to article, DOI:

$10.1039 / \mathrm{b} 310814 \mathrm{~g}$

Publication date:

2003

Document Version

Publisher's PDF, also known as Version of record

Link back to DTU Orbit

Citation (APA):

Han, A., Dufva, M., Belleville, E., \& Christensen, C. B. V. (2003). Detection of analyte binding to microarrays using gold nanoparticle labels and a desktop scanner. Lab on a Chip, 3(4), 329-332.

https://doi.org/10.1039/b310814g

\section{General rights}

Copyright and moral rights for the publications made accessible in the public portal are retained by the authors and/or other copyright owners and it is a condition of accessing publications that users recognise and abide by the legal requirements associated with these rights.

- Users may download and print one copy of any publication from the public portal for the purpose of private study or research.

- You may not further distribute the material or use it for any profit-making activity or commercial gain

- You may freely distribute the URL identifying the publication in the public portal 


\title{
Detection of analyte binding to microarrays using gold nanoparticle labels and a desktop scanner
}

\author{
Anpan Han, ${ }^{b}$ Martin Dufva, ${ }^{a}$ Erik Belleville $^{a}$ and Claus B. V. Christensen*a \\ a BioArray Project, Mikroelektronik Centret (MIC), Technical University of Denmark (DTU), \\ Oersteds Plads 345 East, DK-2800 Kongens Lyngby, Denmark \\ ${ }^{b}$ Institute of Microtechnology, University of Neuchâtel, Rue Jaquet-Droz 1/C.P. 3, CH-2007 \\ Neuchâtel, Switzerland
}

Received 4th September 2003, Accepted 4th September 2003

First published as an Advance Article on the web 25th September 2003

\begin{abstract}
Microarray hybridization or antibody binding can be detected by many techniques, however, only a few are suitable for widespread use since many of these detection techniques rely on bulky and expensive instruments. Here, we describe the usefulness of a simple and inexpensive detection method based on gold nanoparticle labeled antibodies visualized by a commercial, office desktop flatbed scanner. Scanning electron microscopy studies showed that the signal from the flatbed scanner was proportional to the surface density of the bound antibody-gold conjugates, and that the flatbed scanner could detect six attomoles of antibody-gold conjugates. This detection system was used in a competitive immunoassay to measure the concentration of the pesticide metabolite 2,6-dichlorobenzamide (BAM) in water samples. The results showed that the gold labeled antibodies functioned comparably with a fluorescent based immunoassay for detecting BAM in water. A qualitative immunoassay based on gold-labeled antibodies could determine if a water sample contained BAM above and below 60-70 $\mathrm{ng} \mathrm{L}^{-1}$, which is below the maximum allowed BAM concentration for drinking water $\left(100 \mathrm{ng} \mathrm{L}^{-1}\right)$ according to European Union legislation.
\end{abstract}

\section{Introduction}

Microarray technology enabling mass-screening of numerous analytes in a single assay ${ }^{1,2}$ is an attractive alternative to conventional ELISA methods. One of the cornerstones of protein microarray technology is the detection system, where specificity, sensitivity, compatibility with a multiplex format, and low instrument cost are desired properties. ${ }^{3}$ Radioactivity, chemiluminescence, and fluorescence are widely used detection markers for detecting interactions on microarrays, but hampered by the high cost of detection systems. By contrast, a nonexpensive and relatively simple detection method using an office flatbed scanner with a charge-coupled device (CCD) has been described for detecting and quantifying the hybridization of DNA fragments labeled with nanometer-sized gold particles. ${ }^{4}$

Immunoassays based on nanometer-sized gold particles have proved to be adequately sensitive and reproducible for measuring different antigens e.g. human placental lactogen (HPL) by sandwich assays, ${ }^{5-8}$ with sensitivities comparable to ELISA (5.4 pM HPL using $50 \mathrm{~nm}$ large gold particles as labels). Compared to other particle labels such as polymer beads and colloidal dyes, gold nanoparticles are more sensitive for immunoassays. ${ }^{9}$

Since the gold nanoparticle is a robust and inexpensive label we investigated the possibilities to use these for detecting microarray-analyte interactions using a flatbed scanner. The detection system was used to detect 2,6-dichlorobenzamide (BAM), using a competitive immunoassay. ${ }^{10}$ BAM is a breakdown product of dichlobenil which has been a widely used pesticide but has been banned in many countries since unacceptable levels of BAM have been found in drinking water in Europe and the USA.

\section{Experimental}

\section{Reagents and buffers}

2,6-Dichlorobenzamide (BAM) was from Dr. Ehrenstorfer $\mathrm{GmbH}$, (Germany). Tween20, and bovine serum albumin (BSA Fraction V) were from Merck (Germany). Gold sols (10 nm and $20 \mathrm{~nm}$ in diameter), and Tris-HCl were from Sigma (Denmark). BAM hapten-ovalbumin-anthraquinone (BAM-OA-AQ) conjugates were from GEUS (Denmark) and prepared as described by Bruun et al. ${ }^{10}$ Anti-BAM monoclonal antibodies (mAbs) were generated by Statens Serum Institut (Denmark) as described by Bruun et al. ${ }^{10-12}$

\section{Water samples}

Eight water samples from Danish waterworks were kindly provided by Liselotte Clausen (E\&R, Technical University of Denmark, Denmark) and analyzed by GC-MS (Teknologisk Institut, Denmark) and ELISA (GEUS, Denmark).

\section{Labeling of mAbs to gold sols}

Anti-BAM mAbs were conjugated to $10 \mathrm{~nm}$ and $20 \mathrm{~nm}$ gold sols, essentially as described by Slot and Geuze. ${ }^{13}$ Briefly, 50 $\mu \mathrm{L}$ of $\mathrm{mAb}\left(100 \mu \mathrm{g} \mathrm{mL}^{-1}\right)$ were slowly added to $5 \mathrm{~mL}$ of gold sol ( $\mathrm{pH} 8.5$ ). After vortexing for $5 \mathrm{~min}, 500 \mu \mathrm{L}$ of $1 \%$ BSA was added, followed by another $5 \mathrm{~min}$ of vortexing. The antibodygold sol (anti-BAM immunogold) solutions were sedimented by centrifugation for $20 \mathrm{~min}$ at $4{ }^{\circ} \mathrm{C}$ at $8000 \mathrm{~g}$ ( $20 \mathrm{~nm}$ gold sols) or at $20000 \mathrm{~g}(10 \mathrm{~nm}$ gold sols). The supernatant was discarded 
and the anti-BAM immunogold conjugates were resuspended by adding $500 \mu \mathrm{L}$ of ice-cold Tris buffer ( $20 \mathrm{mM}$ Tris, $0.1 \%$ BSA, $\mathrm{pH} 7.4$, Sigma). This washing procedure was repeated six times and the anti-BAM immunogolds were adjusted to an optical density of 5 at $520 \mathrm{~nm}$ (Ultrospec 3000, Amersham Biosciences, Uppsala, Sweden) with Tris-sample buffer (200 $\mathrm{mM}$ Tris- $\mathrm{HCl}, 1.5 \mathrm{M} \mathrm{NaCl}, 1 \%$ BSA, $\mathrm{pH}$ 7.4).

\section{Microarray printing and processing}

BAM hapten-OA-AQ conjugates were diluted to $0.5 \mathrm{mg} \mathrm{mL}^{-1}$ in $1 \times$ Genetix amine spotting buffer (Genetix, UK) and spotted onto CSA microarray substrates (Cell Associates, TX, USA) using a QArray microarray printer (Genetix, UK). Microarray substrates were exposed to UV light at a wavelength of $254 \mathrm{~nm}$ in a Stratalinker 2400 (Stratagene, USA) for $120 \mathrm{~s}$ and the microarray substrates were incubated for $30 \mathrm{~min}$ in TBS block buffer (20 mM Tris- $\mathrm{HCl}, 150 \mathrm{mM} \mathrm{NaCl}, 0.1 \%$ (w/v \%) skim milk powder, $\mathrm{pH}$ 7.5) followed by rinsing twice in Milli-Q water for 5 min each.

\section{Fluorescence BAM assay}

$27 \mu \mathrm{L}$ of sample/standard were pre-incubated for $10 \mathrm{~min}$ with 3 $\mu \mathrm{L}$ of anti-BAM mAb in a final concentration of $100 \mathrm{ng} \mathrm{mL}^{-1}$ in TBS sample buffer. $20 \mu \mathrm{L}$ of each mixture was added to the corresponding arrays and incubated for $1 \mathrm{~h}$ in a humid chamber at either room temperature or at $4{ }^{\circ} \mathrm{C}$. Following incubation, the microarrays were washed for $10 \mathrm{~min}$ in TBST buffer $(20 \mathrm{mM}$ Tris- $\mathrm{HCl}, 150 \mathrm{mM} \mathrm{NaCl}, 0.1 \%$ (v/v \%) Tween20, $\mathrm{pH} 7.5)$ and rinsed twice for $5 \mathrm{~min}$ in Milli-Q water and spin-dried. $20 \mu \mathrm{L}$ of Cy3 labeled goat anti-mouse antibody $\left(1 \mu \mathrm{g} \mathrm{mL}^{-1}\right)$ (Sigma, Germany) was added to each array and incubated for $1 \mathrm{~h}$ and washed as above. Fluorescent $\mathrm{Cy} 3$ emission was acquired with an ArrayWoRx CCD scanner (Applied Precision, WA, USA) and quantified with the ArrayWoRx software.

\section{Immuno gold BAM assay}

Assay procedures were almost identical to the fluorescence assay; however, anti-BAM immunogold mAbs were used instead of unlabeled primary $m A b s$. After incubation, substrates were only dipped into Milli-Q water for washing and spin-dried. Processed arrays were scanned with a flatbed scanner (HP Scanjet 5470c, Hewlett-Packard) with Dias illumination at 2400 dpi resolution, using the accompanying software (HP PrecisionScan Pro, 3.13).

\section{Scanning electron microscopy (SEM) settings}

SEM images were generated using a LEO 1550 field emission scanning electron microscope (Brock \& Michelsen Instruments A/S, Denmark). The acceleration voltage was set to $5 \mathrm{kV}$.

\section{Results and discussion}

\section{Scanning electron microscopy (SEM) characterization of microarrays spots bound with BAM immunogold}

Binding assays were done by applying a buffered solution containing gold nanoparticle labeled antibodies against BAM (anti-BAM immunogold) onto microarrays printed with spots of immobilized BAM. SEM analysis of microarrays after binding assays showed highly packed grains of approximately $20 \mathrm{~nm}$ in diameter distributed across the spot area (Fig. 1a). There was a

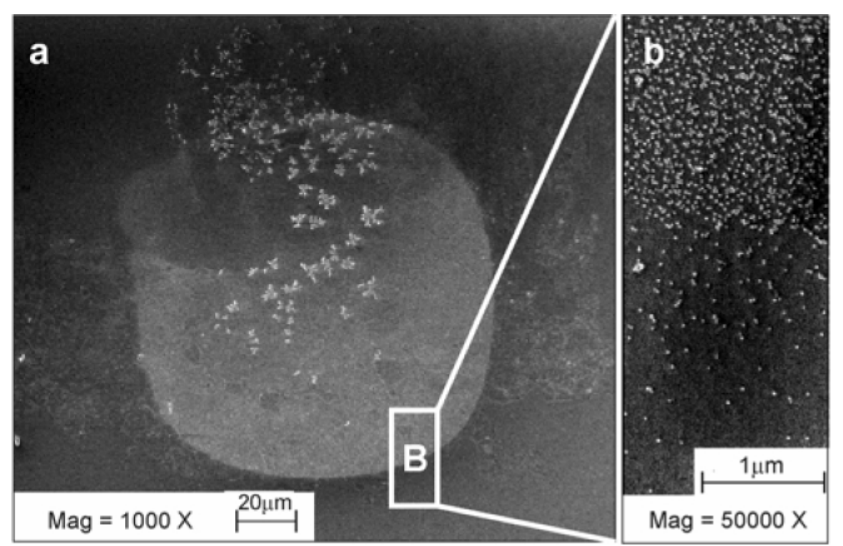

C

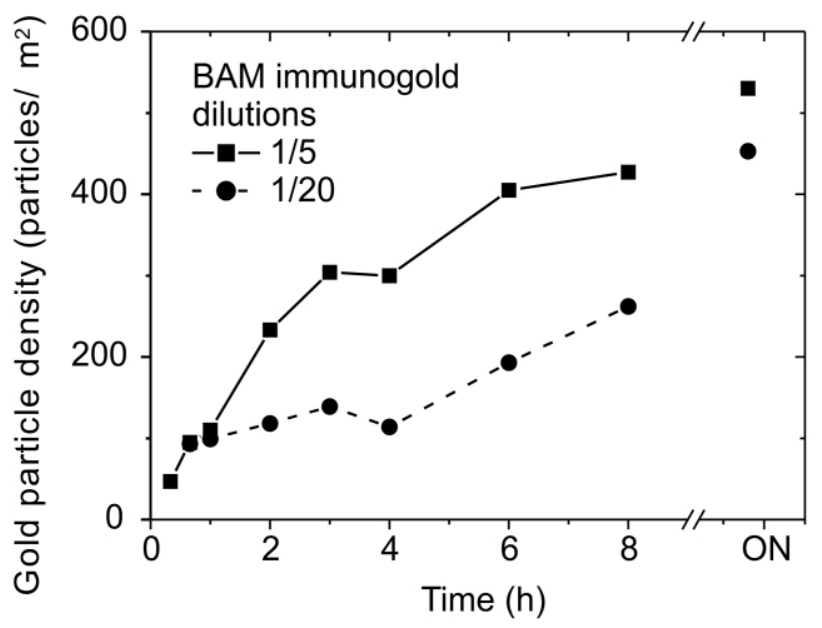

d

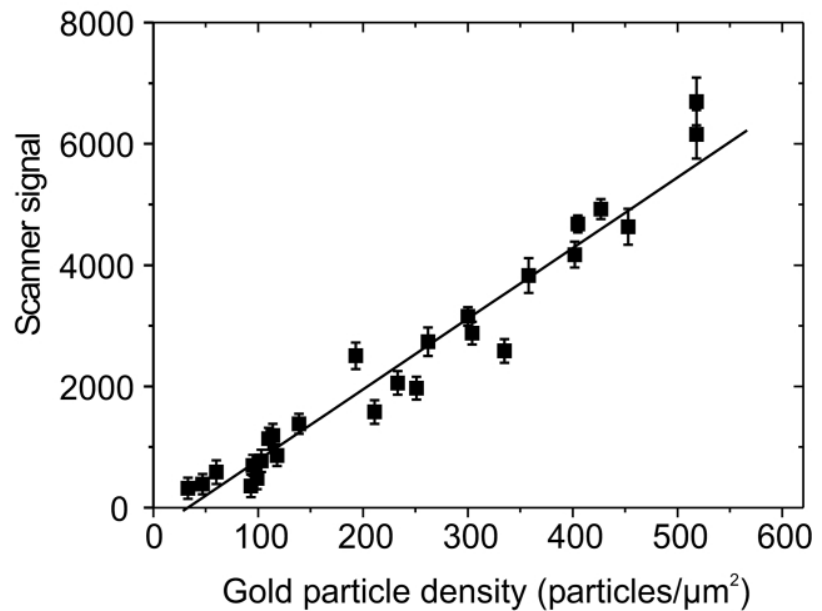

Fig. 1 ( $a$ and b) SEM Characterization of the immunogold assay. BAM microarrays were incubated with a 10 -fold dilution of anti-BAM immunogold for $3 \mathrm{~h}$ at room temperature and processed as described. (a) A $1000 \times$ magnification of a BAM microarray spot. An artifact of presumably precipitated salt grains is visible in the upper inside and outside area of the spot. (b) The rectangle denoted in (a) shows a $50000 \times$ magnification magnifying the spot borders. (c) Kinetics of anti-BAM immunogold binding to immobilized BAM antigens. BAM microarrays were incubated with 5 -fold or 20-fold dilutions of anti-BAM immunogold for between $20 \mathrm{~min}$ and overnight. After processing, the microarrays were analyzed by SEM at $100000 \times$ magnification. Particle densities were counted manually. The total particle count for each data-point was between 73 and 427. (d) Correlation between the desktop scanner spot signals and the SEM determined the number of bound particles $\mu \mathrm{m}^{2}$. Spots with different amounts of bound gold anti-BAM conjugates as determined with SEM were analyzed and quantified with the flatbed scanner. The scanner signal ( $Y$ axis) was expressed as mean value of all four spots per microarray was plotted against the gold particle density ( $X$-axis). Figure error bars represent the standard deviation. Linear fit correlation coefficient $=0.976$, line equation: scanner signal $=12 \times$ particle density -400 . 
clear difference in gold particle density between the spots and the surroundings, suggesting that the binding was highly specific to immobilized hapten (Fig. 1a). To evaluate the binding kinetics of immunogold to the microarray spots, microarrays with immobilized BAM hapten were incubated between $15 \mathrm{~min}$ and overnight with solutions containing different amounts of anti-BAM immunogold. The immunogold binding rate to the microarray spots appeared to be linear up to a density of 300 particles $\mu \mathrm{m}^{2}$ (Fig. 1c), which is similar to the results obtained by previous studies. ${ }^{14,15}$ A 20 -fold dilution of anti-BAM immunogold was slower to reach the density of 300 particles $\mu \mathrm{m}^{2}$ compared to a 5-fold dilution. After overnight incubation, an array spot density of around 500 particles $\mu \mathrm{m}^{2}$ incubation was established independent of the initial concentration of immunogold, suggesting this to be the maximum number of gold particles that could be bound to the array spot surface. This saturation is most likely due to steric hindrance since decreasing particle size allowed for higher surface densities. ${ }^{13-15}$ A gold particle density of 500 particles $\mu \mathrm{m}^{2}$ was calculated to approximately cover $15 \%$ of the spot surface.

Spots with varying gold particle densities were used to correlate the signal output from a 2400 dpi office flatbed scanner to the SEM determined surface density of bound immunogold particles. A linear correlation was found between the scanner signal and the gold particle density, between the lowest detectable density of 50 particles $\mu \mathrm{m}^{2}$ up to the maximum density of 500 particles $\mu \mathrm{m}^{2}$ (Fig. 1d). The lowest detectable density was defined as the gold particle density found at $2 \times \mathrm{SD}$ (standard deviation) of the scanner background signal. Since the area scanned was approximately $70000 \mu \mathrm{m}^{2}$, ( 4 circular spots of about $150 \mu \mathrm{m}$ in diameter), it was calculated that $6 \times 10^{-18} \mathrm{~mol}$ of anti-BAM immunogold conjugates could be visualized with the flatbed scanner which is 6-fold more than the 1 attomol of streptavidin coated gold particles that could be detected with a CCD camera after silver enhancement. ${ }^{16}$

\section{Comparison of immunogold and fluorescence assays}

The reproducible binding of anti-BAM immunogold conjugates to surface-immobilized BAM-haptens indicated that gold particles could be a suitable detection label for microarrays. The anti-BAM immunogold was compared to an identical fluorescence assay by exposing the respective antibody to a dilution series of BAM. Both the immunogold assay and the fluorescence assay resulted in similar standard curves although the $\mathrm{IC}_{50}$ values (Inhibition Concentration: analyte concentration that gives $50 \%$ signal reduction) and detection limits were slightly better for the fluorescence detection (Fig. 2).

Intra (replicas of assays) and inter-assay variation (assays were performed on different days and different batches of printed microarrays) of the immunogold assay was relatively low (up to $17 \%$ as determined from triplicate experiments) within the dynamic range. In comparison, the variance of the fluorescence assay was generally lower than for the immunogold assays (intra assay variations of $1-11 \%$ and inter assay of $4-16 \%$ ).

\section{Qualitative BAM immunogold assay}

In order to increase the sensitivity of the immunogold assay, the initial immunogold concentration was diluted 100 fold and the reaction with the microarray was performed at $4{ }^{\circ} \mathrm{C}$. These conditions reduced the signal significantly resulting in a qualitative assay that could detect BAM levels at cutoff levels of 50-100 ng L $\mathrm{L}^{-1}$ as determined by a dilutions series of BAM (data not shown). Eight water samples was analyzed using the BAM immunogold assay under these conditions and the results showed samples containing $\geq 70 \mathrm{ng} \mathrm{L}^{-1} \mathrm{BAM}$ according to
GC-MS and ELISA analysis was recorded as BAM positive in the test (no signal) while sample 8 provided a signal tested to contain $60 \mathrm{ng} \mathrm{L}^{-1}$ BAM. Thus, the cutoff concentration of the BAM immunogold assay was estimated to be around 60-70 ng $\mathrm{L}^{-1}(320-370 \mathrm{pM})$ of BAM. The immunogold assay was validated further by testing all the samples in a 20 -fold dilution. As expected, signals were obtained for all diluted samples, since sample concentrations now were below the approximated immunogold assay cutoff concentration of $60-70 \mathrm{ng} \mathrm{L}^{-1}$ of BAM. This detection level was below $100 \mathrm{ng} \mathrm{L}^{-1}$, which is the highest allowed BAM level in water according to current EU legislations. The BAM immunogold assay used the same antiBAM mAb clone as described by Bruun et al. ${ }^{10}$ for the BAMELISA, which had a practical detection limit of $20 \mathrm{ng} \mathrm{\textrm {L } ^ { - 1 }}$. Consequently, the immunogold assay is 3 -fold less sensitive than the corresponding ELISA, however, the immunogold assay is experimentally simple to perform compared to the traditional ELISA assay, which requires several washing and incubation steps. Compared to dipstick pesticide assays ${ }^{17,18}$ that have total assay times between 30 and $90 \mathrm{~min}$, the immunogold assay as performed here has a longer incubation time. However, the immunogold assay is 8-fold more sensitive compared to the dipstick assays, and thus applicable to be developed into other and more sensitive screening applications. Furthermore, this detection system could also be used in other analyte screening applications based on different assay formats, e.g. sandwich immunoassays, where high concentrations of immunogold

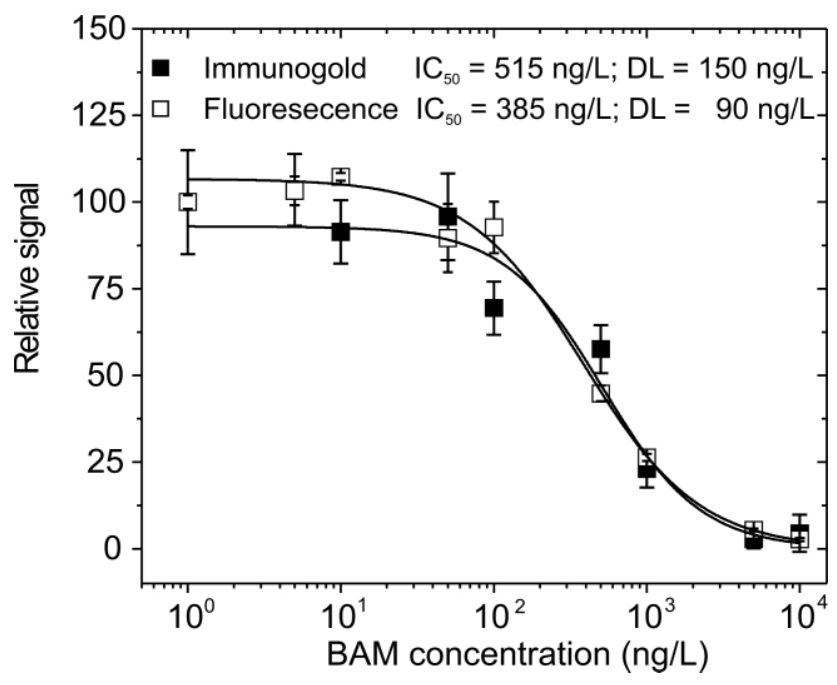

Fig. 2 Comparison of standard curves determined for the fluorescence and immunogold assay BAM assays. In the fluorescence assay, BAM standards ranging from zero to $10000 \mathrm{ng} \mathrm{L}^{-1}$, were mixed with $1 \mu \mathrm{g} \mathrm{mL}^{-1}$ of unlabeled anti-BAM mAbs followed by incubation with secondary Cy3labeled goat anti-mouse. The immunogold assay standard curves were obtained similar to the fluorescence assay, however, using a 20-fold dilution of anti-BAM immunogold and with overnight incubation at room temperature. Standard curves and 4-parameter-logistic fits ${ }^{19}$ were generated with Origin 6.1 (Originlab, USA). Fluorescence assays were performed in triplicate while the immunogold assay was performed in nine replicates. Figure error bars represent the standard deviation.

Table 1 Test of BAM in water samples

\begin{tabular}{lllllllll}
\hline Sample & 1 & 2 & 3 & 4 & 5 & 6 & 7 & 8 \\
\hline GC-MS/ng L $^{-1}$ & 340 & 230 & 210 & 180 & 150 & 130 & 70 & 60 \\
ELISA/ng L $^{-1}$ & 350 & 290 & 190 & 170 & 150 & 110 & 80 & 60 \\
Immunogold $^{a}$ & - & - & - & - & - & - & - & + \\
Control $^{b}$ & + & + & + & + & + & + & + & +
\end{tabular}

${ }^{a}$ Each sample was tested in triplicate by BAM immunogold assay. (+) indicates a spot signal (indicating that BAM levels were below the cutoff level) and ( - ) that the signal could not be detected (indicating that BAM levels were above the cutoff level). ${ }^{b}$ The water samples were diluted 1:20 prior to analysis with the BAM immunogold assay. 
could be used and hence the assay time could be reduced significantly.

\section{Acknowledgements}

We gratefully acknowledge Professor G. Hansen, The Panum Institute at The University of Copenhagen, for valuable advice concerning labeling of antibodies with gold nanoparticles. This work was financially supported by the Danish Research Council (SUE project no. 2027-00-0005 and DABIC project no. 2014-00-0003).

\section{References}

1 E. S. Lander, Nat. Genet., 1999, 21, 3 .

2 C. Christensen, Talanta, 2002, 56, 289.

3 B. Schweitzer and S. F. Kingsmore, Curr. Opin. Biotechnol., 2002, 13, 14.

4 T. A. Taton, C. A. Mirkin and R. L. Letsinger, Science, 2000, 289, 1757.

5 J. H. Leuvering, P. J. Thal, M. van der Waart and A. H. Schuurs, J. Immunoassay, 1980, 1, 77 .
6 J. H. Leuvering, P. J. Thal, M. Van der Waart and A. H. Schuurs, J. Immunol. Methods, 1981, 45, 183.

7 J. H. Leuvering, P. J. Thal and A. H. Schuurs, J. Immunol. Methods, 1983, 62, 175.

8 W. D. Geoghegan, S. Ambegaonkar and N. J. Calvanico, J. Immunol. Methods, 1980, 34, 11.

9 T. C. Gribnau, J. H. Leuvering and H. van Hell, J. Chromatogr., 1986, 376, 175.

10 L. Bruun, C. Koch, B. Pedersen, M. H. Jakobsen and J. Aamand, J. Immunol. Methods, 2000, 240, 133.

11 L. Bruun, C. Koch, M. Jakobsen, B. Pedersen, M. Christiansen and J. Aamand, Anal. Chim. Acta, 2001, 436, 87.

12 L. Bruun, C. Koch, M. Jakobsen and J. Aamand, Anal. Chim. Acta, 2000, 423, 205.

13 J. W. Slot and H. J. Geuze, Eur. J. Cell Biol., 1985, 38, 87.

14 K. Park, S. Simmons and R. Albrecht, Scanning Microsc. Suppl., 1987, 1, 339.

15 K. Grabar, P. Smith, M. Musick, J. Davis, D. Walter, M. Jackson, A. Guthrie and M. Natan, J. Am. Chem. Soc., 1996, 118, 1148.

16 I. Alexandre, S. Hamels, S. Dufour, J. Collet, N. Zammatteo, F. De Longueville, J. L. Gala and J. Remacle, Anal. Biochem., 2001, 295, 1 .

17 L. Mosiello, C. Cremisini, L. Segre, S. Chiavarini, M. Spano, T. Kimmel, A. Baumner and R. Schmid, J. Agric. Food Chem., 1998, 46, 3847.

18 N. Cuong, T. Bachmann and R. Schmid, Fresenius J. Anal. Chem., 1999, 364, 584.

19 D. Rodbard, Clin. Chem., 1974, 20, 1255. 